\title{
The Effect of Korean Culture and Its Impact on International Business
}

\author{
${ }^{1}$ Mahadi Hasan Miraz, ${ }^{2}$ Dr. Md. Mamun Habib, ${ }^{3}$ Mohammad Ismail Majumder \\ ${ }^{1}$ School of Quantitative Sciences (SQS), Universiti Utara Malaysia, Malaysia \\ ${ }^{2}$ BRAC School of Business (BBS), BRAC University, Bangladesh \\ ${ }^{3}$ Faculty of Business Administration, Khulna University, Bangladesh \\ Email: ${ }^{1}$ mahadimiraz1@gmail.com, ${ }^{2}$ mamunhabib@bracu.ac.bd, ${ }^{3}$ dmajumder84@yahoo.com
}

\begin{abstract}
Different countries have dissimilar cultures from the influence of its religions, tradition, norms and ritual. South Korea has its unique cultures and these cultures influence people's daily lives as well as its business performance, especially in international business. It is essential for foreigners or multinational companies in South Korea to understand those cultures and use them suitably to work better with Korean employees or partners. This paper mainly focuses on six parts of the Korean culture, which are Kibun, Inhwa, the power distance and hierarchy, Confucianism, the personal relationships in doing business, and business custom in Korea. All of these critical aspects of the Korean culture have strong influences on the way how to do business in South Korea. Without understanding them, it is hard particularly for foreigners and foreign companies to do their business in Korea efficiently and proficiently and have all successes in their business in Korea.
\end{abstract}

Keywords: Korean culture, cultural dimension, confucianism, Korean business etiquette, K-Type management.

\section{Introduction}

South Korea, by means of the official name of Republic of Korea (ROK), is situated in East Asia. It has nine provinces and six special cities, with the population of approximately 50 million. It has extended past, and even though it has interactions with China and Japan for a long time, it produced its exclusive culture and advanced its own tradition. Indeed, the Korean culture is very dissimilar from not only Western cultures, but also neighboring countries' cultures in every feature of culture. Even though some components of the culture are alike to Chinese and Japanese ones, cultural differences make the way to do commercial in Korea different from other countries, particularly from China or Japan. This is the reason why this paper will inspect some of major aspects of unique Korean cultures which give significant influences on doing business in Korea. Even though there are more cultural features that effect its business practices in Korea, those specific items of Korean culture are the most important ones concerning doing business in Korea by foreigners or multinational companies.

\subsection{Research Objectives}

1. To identify the unique cultures and these cultures' influence especially in international business.

2. To understand the strategies of multinational companies in South Korea for working with Korean employees or partners.

3. To enhance the Cross Country Research among Asian countries and find International Competitiveness of Asian Economies.

\section{Conceptual Framework}




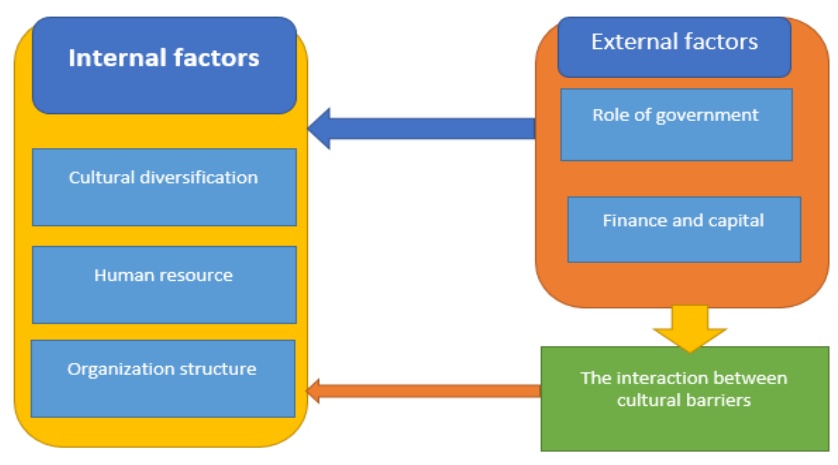

Figure 1. Conceptual framework

\section{$2.1 \quad$ Hypothesis}

There is a positive relationship between habituate of Korean cultural and increases of international business.

\section{$3 \quad$ Method and Data}

For a critical analysis of how the Korean culture has been portrayed in the media, this research will review scholarly studies on the topic and examine prominent newspapers from different countries. Sources included academic journals, news articles, edited books, websites, and newspapers. Research was also conducted for qualitative data by face-to-face and phone interviews.

This research will focus on a comparative framing analysis on the Korean culture from U.S., Asian, and Korean newspapers. Only major newspapers were selected based on their nationwide standing in each country: Korea Herald, Korea Herald (Singapore), Korea Herald (Thailand) and Korea Herald (Tokyo). Articles were collected from online archives with the searching keywords of "Korean culture and business initiatives."

\section{Discussion}

\subsection{Critical Aspects of Korean Culture for Business Practices in Korea}

\subsubsection{Kibun}

As one of the most important key aspect of the Korean culture, which influences the way to do business in South Korea significantly, Kibun does not have direct English translation. It basically means a mood or feeling of balance and good behavior [3]. In South Korea, people are continuously trying to maintain the environment of stable Kibun, both in personal life and business world. People are willing to maintain their own Kibun as well as others'.

\subsubsection{Inhwa}

Another key principle of South Korean business culture is Inhwa, which is defined as harmony. As a collectivist society, consensus is an important element in promoting and maintaining harmony in South Korea. Inhwa was drawn from Confucian beliefs, and stresses harmony between people, especially unequal. Usually Koreans like to give positive answers and avoid or reluctant to give direct refusals. They do not want to hurt the harmonious environment by giving negative answers or refusing others to cause face losing. Inhwa usually exists in unequal of rank, prestige and power. In the business world, this term requires that subordinates be loyal to their superiors and that superiors be concerned with the well-being of subordinates [2]. 


\subsection{Power Distance and Hierarchy in South Korea}

Compared with the greet Hofstede cultural dimensions of United States, south Korea has higher power distance [3]; [8]. The comparison chart is showing on the right. This indicates that the society has higher level of inequality, and individuals and society in South Korea are more unequal than those in the United States. The comparison of United States and South Korean Geert Hofstede Cultural Dimensions explains the atmosphere that the American or other foreigners face in their daily business with Korean business partners or employees. Many foreigners who visit Korea for the first time are usually surprised at that mostly.

Koreans bow to others, especially elders, and that younger persons need to wait until the elders and those who with high hierarchy rankings get their food [7].

\subsection{Personal Relationships for Doing Business}

In South Korea, the individual relations are important for doing business, and usually established before the beginning of the business process. In order to be successful, it is vital to establish good personal relationships based on mutual trust and benefit. Korean business culture is firmly grounded in respectful rapport [9]. In order to establish the personal relationships, it is very helpful to be introduced by a mutual friend or acquaintance at the appropriate level. Therefore, time should be allocated for this process, particularly during the first meeting, which is frequently used to simply establish rapport and build trust. Once good, solid relations have been recognized in South Korea, continuous reinforcement and maintenance is vital [4]; [6].

\subsection{South Korean Business Etiquette}

South Korea has its own unique business etiquette, and all of the etiquette is influenced by their unique cultures in some extent. Obtaining this culture is vital for foreign companies to do better business with South Korea. South Korean unique business protocol mainly displays in six aspects, which are introduction, greeting, business cards, business meeting, K-Type management style, and gift giving.

\subsubsection{Salutation}

In South Korea, greeting is one of the steps that businessmen do not want to skip. It usually happens after the introduction. The usual greeting between men is a bow, accompanied by a handshake. To show respect, the left hand is placed below the right forearm while shaking hands. Women do not shake hands as frequently as men [3]. During greeting, maintaining the eye contact is appreciated.

\subsubsection{Commercial Cards}

South Koreans attach importance to business cards exchange, with their certain way. Usually, after the handshake, business cards are exchanged between professionals during initial encounters. The cards are presented and received with both hands. After receiving the card, it is suggested to nod your head to show your respect and thanks. Once you receive it, try not to stare too hard at those business cards as it will come across as impolite and/or possibly offend the Korean businessmen [9].

\subsubsection{Business Meeting}

Since business is based on personal relations and trust in South Korea, typically it takes longer to complete a deal. Therefore, it usually takes several meetings to finish the business. The first meeting is usually a start of the business-relationship building process. Very little might be discussed which relates to the actual business in hand for a while, with most time being spent exchanging pleasantries, discussing travel and other small trivia [4]; [10].

\subsubsection{K-Type Management Style}

Because South Korea is a society with high power distance and hierarchy, the management style is quite different from that in the United States or many other Western countries, which have lower power distance. Therefore, Korean management style, called K-Type management, consists of top down decision-making, paternalistic leadership, clan management, personal loyalty, compensation based on seniority and merit ranking, high mobility of workers. The organization structure of companies are highly centralized and formalized with authority focused in senior levels. Major decisions go through a formal procedure of approval from top levels of management ([1]; [2]; [4] \& [5]. 


\subsubsection{Gift Giving}

In South Korea, gift giving is part of doing business. It is done to secure favors and build relationships [9]. Gift giving in South Korea is not seen as a bribery or corruption. Normally, business gifts should be of good quality but inexpensive. The gifts from the givers' home country would be much appreciated and impressive, regardless of the price. The gifts should be wrapped before giving, and opened in private rather than in the presence of the giver. When handing out more than one gift, the giver(s) need to make sure that senior members are given gifts with greater value than junior members, because respect for seniors is everything in South Korea [1].

\subsubsection{Benefits}

Foreigners and foreign companies will be more familiar with the way how to do business with Koreans and in Korea. If they understand more about the Korean value system based on its culture and recognize the impact of South Korean unique cultures to its business. The more foreigners understand the Korean culture, the more they could enjoy their business with Koreans and in Korea. Korean will get more efficient, flexible, innovative, and responsive to their business. The research will help to identify several key internal and external factors that impact on the ability of enterprises to compete successfully in international markets. These include the role of human resource development, the organizational structure, as well as the technological capability of firms. We argue that generally the pursuit of dynamic upgrading that allows firms to maintain their competitiveness may be captured by the notion of learning.

\section{$5 \quad$ Discussion}

This research discusses the Korean culture and business tradition. This discussion relate similar works in different business strategies. This research is hoped to be served as a guideline or reference similar field of future research. All of these critical aspects of the Korean culture have strong influences on the way how to do business in South Korea. Without understanding them, it is hard especially for foreigners and foreign companies to do their business in Korea effectively and efficiently and have all successes in their business in Korea.

\section{Conclusions}

Various companies have been doing business with Korean and Korean firms for the last decade as many Korean companies become major players in global markets with their impressive performance. As foreigners and foreign companies are more involved in business with Korean and Korean companies, they would often face some difficulties of handling their daily business with Korean and Korean business people because of different expectation, practices and behaviors in each stage of business. Most of those differences come from cultural differences between Korea and other countries. Although Korea is regarded as one of the most internationalized or Westernized countries overall in Asia, many Koreans still keep their traditional culture very much and follow their tradition, custom and practice developed from their culture significantly in doing business. So, understanding the Korean culture, tradition and custom helps foreigners and foreign companies do their business with Korean and/or in Korea efficiently and effectively and finally enjoy all kinds of successes with their business.

\section{References}

1. Aiken, M., Kim, D., Hwang, C., and Lu, L. (1995). "A Korean Group Decision Support System", Information and Management, 28 (5), 303-310.

2. Alston, J.P. (1989). "Wa, Guanxi, and Inhwa: Managerial Principles in Japan, China and Korea", Business Horizons, 32 (2), 26-31.

3. Chaney, L. H., \& Martin, J. S. (2011). Intercultural business communication (5th ed.). Upper Saddle River, N.J.: Prentice Hall.

4. Chen, M. (2004). Asian Management Systems: Chinese, Japanese and Korean Styles of Business, Cengage Learning EMEA. 
5. Cho, Y.H., and Yoon, J. (2001). "The Origin and Function of Dynamic Collectivism: An Analysis of Korean Corporate Culture", Asia PacificBusiness Review, 7 (4), 70-88.

6. Kim, S., and Briscoe, D.R. (1997). "Globalization and a New Human Resource Policy in Korea: Transformation to a performance -based HRM", Employee Relations, 19 (4), 298-308.

7.Lee, S., Brett, J., and Park, J.H. (2012). "East Asian's Social Heterogeneity: Differences in Norms among Chinese, Japanese and Korean Negotiators", Negotiation Journal, 28 (4), 429-452.

8. Sama, L.M. and Papamarcos, S.D. (2000). "Hofstede's I-C Dimension as Predictive of Allocative Behavior: A Meta-Analysis", International Journalof Value-Based Management, 13 (2), 173-188.

9. Southerton, D.G. (2008). More thoughts on Korean Business and Popular Culture: Volume 2, Bridging Culture Publications Von Gilnow, M.A., Huo.

10.Pelham, A.M. (1997). "Eastern and Western Business Tactics", Journal of East-West Business, 3 (3), 45-65. 